\title{
Література:
}

1. Закон України «Про внесення змін до Конституції України (щодо правосуддя) від 2 червня 2016 р. // База даних «Законодавство України». URL: https://zakon.rada.gov.ua/laws/show/1401-19\#n2

2. Закон України «Про внесення змін до Господарського процесуального кодексу України, Цивільного процесуального кодексу України, Кодексу адміністративного судочинства України та інших законодавчих актів» // Електронний ресурс. - Режим доступу: https://zakon.rada.gov.ua/laws/show/2147\%D0\%B0-19

3. Див: Gap-Аналіз впровадження інституту медіації в Україні, підготовлений в рамках реалізації проекту СС Право-Justice. 2020. - С. 10-12 // Електронний ресурс: режим доступу: https://www.pravojustice.eu/storage/app/uploads/public/5f5/f7d/2a9/5f5f7d2 a9b5cb356474501.pdf

DOI https://doi.org/10.30525/978-9934-26-040-7-3

\section{ПОЛІТИКА ТА ЗАКОНОДАВСТВО ПНР ЩОДО НАЦІОНАЛЬНИХ МЕНШИН}

\author{
Дедурін Г. Г. \\ кандидат історичних наук, доцент, \\ доиент кафедри теорії та історії держави і права \\ факультету № 1 \\ Харківського начіонального університету внутрішніх справ \\ м. Харків, Україна
}

Геополітичні наслідки Другої світової війни привели не тільки до зміни характеру польської держави, яка перетворилася на Польську народну республіку (ПНР) - країну соціалістичного табору, але й істотно відкоригували державний курс щодо національних меншин. Нацистська окупаційна політика, спрямована на знищення цілих національних груп, як-то євреїв, циган, а також повоєнна зміна кордонів, особливо на сході, спричинили істотні зміни у національній структурі Польщі у порівнянні 3 міжвоєнним періодом. 3 перших повоєнних років польська комуністична влада була налаштована на побудову централізованої держави у якій не залишилось би місця 
національним меншинам, а національність та громадянство стали б синонімічними поняттями.

Така мета цілком виправдовувала проведені у II пол. 1940-х pp. етнічні чистки та акції насильницького виселення або переселення окремих національних груп, зокрема українців і німців, що активно заохочувалося Москвою. Розпорошення національних груп, які компактно проживали у прикордонних землях, на думку тогочасної польської влади, зменшувало вірогідність територіальних претензій до Польщі з боку СРСР, Німеччини та Чехословаччини.

На початку 1950-х рр., стверджує польська дослідниця А. Маліцька, мала місце деяка лібералізація урядової політики щодо національних меншин, яка виявилася у дозволі їх представникам відкривати власні школи, організовувати освітньо-культурні товариства, що отримували державну допомогу та ставали офіційними осередками меншин у новій польській державі [1, s. 58]. Ці зміни, які переважно стосувалися української та німецької меншин, можна пояснити стабілізацією ситуації у західних і північних землях країни разом з бажанням влади нівелювати негативні настрої в українській та німецькій спільнотах, спричинені операцією «Вісла» й насильницькими виселеннями.

Втім, у Конституції ПНР від 22 липня 1952 р. правовий статус національних меншин визначено не було. Сдиний натяк на їх існування можна було знайти у п. 2 ст. 67 Конституції, де зазначалося, що усі громадяни ПНР, не дивлячись на їх расову, релігійну або національну приналежність, наділені рівними правами [2, art. 67]. Крім цих загальних положень задекларованих у Конституції, жодних інших законодавчих актів спрямованих на врегулювання становища національних меншин у Польщі довгий час не було, тому чималого значення набувають різні партійні постанови, які стосувалися даної проблеми.

Привертає увагу постанова Президіуму Ради Міністрів, яка 3'явилася наприкінці 1954 р., де було зазначено, що у ПНР різні національні групи мають конституційно гарантовані рівні права у всіх сферах життя суспільства - політичній, господарчій, культурній. Водночас, у цій же постанові наголошувалося, що у певної частини суспільства ще збереглися «буржуазні упередження» стосовно національних меншин, і на практиці це викликає прояви дискримінації та порушення конституційних прав. Отже, констатувалося у документі, практичне становище меншин не завжди відповідало їх правовому статусу, зафіксованому у Конституції [3, s. 95 - 96]. Подібні відвертості демонструють, що відсутність належної правової бази захисту меншин, 
робило цю групу однією з найбільш вразливих категорій суспільства у Польській народній республіці.

Після приходу до влади у жовтні 1956 р. В. Гомулки, дискурс політики щодо національних меншин, в цілому, не зазнав істотних змін і базувався на наступних переконаннях:

- інша від польської національність не є приводом до дискримінації, але водночас вона не $\epsilon$ й підставою для отримання якихось особливих прав, зокрема у суспільно-політичній сфері;

- меншості та їх організації становлять інтегральну частину існуючої політичної системи, тому, насамперед, вони мають сприяти зростанню лояльності різних суспільних груп до політики держави, а не опікуватися інтересами їх членів;

- не були засуджені репресивні дії щодо національних меншин, які мали місце у II пол. 1940-х рp. [4, s. 47].

Тим не менш, нова політична реальність, яка настала після подій 1956 р., змусила владу де в чому відійти від старих методів контролю та обмеження активності національних меншин. На хвилі певної лібералізації режиму, було дозволено діяльність їх об'єднань, але не більше одного на кожну групу, до того ж ці об'єднання мали перебувати під постійним контролем міністерства внутрішніх справ. Деякі позитивні зрушення спостерігалися й у сфері видання меншинами власної преси, розширенні мережі культурно-освітніх закладів, неформально, але без суттєвих перешкод з боку влади, могла діяти греко-католицька церква [5, с. 153].

Окремі поступки, не підкріплені на законодавчому рівні, не могли вирішити усіх проблем меншин. Більш того, у 1976 р. у постанові III пленуму правлячої Польської об'єднаної робітничої партії (ПОРП) взагалі було наголошено на гомогенності країни у національному відношенні $[1$, с. 58]. Природно, що такий підхід залишав вкрай мало можливостей для повноцінного суспільно-політичного або культурноосвітнього життя представників національних меншин.

Ситуація почала змінюватися з активізацію опозиційного руху у Польщі на початку 1980-х рр. Лідери незалежної профспілки «Солідарність», вже на I з'їзді своїх делегатів, що відбувся у листопаді 1981 р. у Гданську, звернулися до проблеми національних меншин у підсумковій постанові, наголосивши на «невід'ємному праві меншин на необмежений розвиток власної національної самосвідомості» [6, с. 9]. На цьому етапі, до проблем меншин все частіше почав звертатися й костьол. Ще з середини 1980-х рр. у деяких костьолах богослужіння почали відправлятися німецькою мовою. 
Напередодні перших демократичних виборів до сейму, призначених на 4 червня 1989 р., було створено Національний громадський комітет, у рамках якого розпочала свою дію Комісія у справах національних меншин, що мала розробити засади правового регулювання становища представників національних меншин у Польщі [6, с. 10]. Нарешті, офіціальне визнання владою існування проблеми меншин та необхідності розбудови системи захисту їх прав на вільний національнокультурний розвиток, відбулося під час промови у вересні 1989 р. голови першого не комуністичного уряду Т. Мазовецького.

В останні місяці існування ПНР також розпочалася інституціоналізація політики органів державної влади щодо національних меншин. Так, було утворено сеймову комісію у справах національних та етнічних меншин, крім того, аналогічна комісія почала працювати й при міністерстві культури й мистецтва [7, с. 110]. Одним 3 головних завдань, поставлених перед ними, була розробка законодавчих норм, які б регулювали правове становище національних меншин у вільному від комуністичного диктату польському суспільстві. Перші практичні результати роботи комісій, які вдалося конвертувати у правозастосовну практику, мали місце вже у 1990-х рр.

\section{Література:}

1. Malicka A. Status prawny mniejszości narodowych i etnicznych w Polsce - ustawa o mniejszościach narodowych i etnicznych oraz języku regionalnym. E-Wydawnictwo. Prawnicza $i$ Ekonomiczna Biblioteka Cyfrowa. Wydziat Prawa, Administracji $i$ Ekonomii Uniwersytetu Wrocławskiego. 2017. S. 55-78.

2. Dziennik Ustaw z 1976 r. Nr 7, poz. 36. Art. 67. URL: https:// isap.sejm.gov.pl/isap.nsf/ByYear.xsp?type $=$ WDU\&year $=1976 \& v o l=7$

3. Mironowicz E. Polityka narodowościowa PRL. Białystok: Białoruskie Towarzystwo Historyczne, 2000. 284 s.

4. Madajczyk P. Mniejszości narodowe w Polsce po II wojnie światowej. Pamięć i Sprawiedliwość. 2004. № 2. S. 37-55.

5. Syrnyk M. Ukraińcy w powiecie wałeckim $-\mathrm{z}$ najnowszych dziejow mniejszości ukraińskiej w Polsce 1947 - 2000. Ukraińcy $w$ najnowszych dziejach Polski (1918 - 1989). Słupsk - Warszawa 2000. S. 150 - 155.

6. Łodziński S. Struktura narodowościowa Polski i polityka wobec mniejszości w latach 1989-1992. Kultura $i$ Spoteczeństwo. 1992. № 3. S. 8-12.

7. Malicka A. Ochrona mniejszości narodowych - standardy międzynarodowe i rozwiązania polskie. Wrocław: Wyd. Uniwersytetu Wrocławskiego, 2004. 247 s. 